\title{
Fragile $X$ syndrome carrier screening in the prenatal genetic counseling setting
}

Amy Cronister, $M S^{1}$, Miriam DiMaio, $M S W^{2}$, Maurice J. Mahoney, MD, JD ${ }^{2}$, Alan E. Donnenfeld, $M D^{1}$, and Stephanie Hallam, $\mathrm{PhD}^{1}$

\begin{abstract}
Purpose: To document our experience with fragile X carrier screening. Methods: In this study, 29,103 women with no known or suspected family history of fragile $X$ syndrome were offered fragile $X$ carrier screening during their prenatal genetic counseling visit. Screening acceptance was analyzed by referral indication, carrier frequencies documented, and prenatal outcome data presented. Results: Overall, 7.9\% accepted carrier screening. The premutation frequency was 1 in 382, and the intermediate allele frequency was 1 in 143. Conclusions: Fragile $X$ screening is a desirable option for some women seeking prenatal genetic counseling and should be made available to this population. Genet Med 2005:7(4):246-250.
\end{abstract}

Key Words: Fragile $X$ syndrome, genetic screening, carrier testing, prenatal genetic counseling, FMR-1

Fragile $\mathrm{X}$ syndrome is among the most common human genetic disorders leading to mental impairment in both males and females. Since Lubs ${ }^{1}$ first described the cytogenetic findings associated with this condition in 1969, significant advances have been made in our understanding of the broad spectrum of physical, cognitive, emotional, and behavioral involvement in affected individuals. With the discovery of the FMR1 gene in 1991, the underlying cause of fragile $\mathrm{X}$ syndrome was identified and the mystery of fragile $\mathrm{X}$ syndrome's unique inheritance pattern was unraveled. ${ }^{2-5}$ The fragile $\mathrm{X}$ mutation was shown to be an unstable CGG trinucleotide repeat capable of expansion when transmitted from mother to child. Prevalence studies suggest that 1 in 4000 males and 1 in 8000 females are affected by the condition ${ }^{6}$ and approximately 1 in 260 females and 1 in 800 males is a premutation carrier (CGG repeat of $\geq 55) .7,8$ Based on these prevalence figures, fragile $\mathrm{X}$ syndrome is thought to be underdiagnosed.

The American College of Medical Genetics Policy Statement on fragile X syndrome ${ }^{9}$ recommends fragile $\mathrm{X}$ testing for individuals with mental retardation, autism, and learning difficulties and for individuals with a family history of undiagnosed mental retardation. Targeted screening has been successful in identifying many undiagnosed families yet the majority of carrier females remain undetected and unaware of their reproductive risks. A number of studies have evaluated the feasibility and efficacy of general population screening for women of reproductive age. Palomaki ${ }^{10}$ was among the first to conclude that fragile X syndrome met population-based screening crite-

\footnotetext{
From ${ }^{1}$ Genetic Services and Molecular Diagnostic Laboratory, Genzyme Genetics, Westborough, Massachusetts; ${ }^{2}$ Department of Genetics, Yale University School of Medicine, New Haven, Connecticut.

Amy Cronister, MS, Genzyme Genetics, 9042 N Arroya Vista Dr, Phoenix, AZ 85028.

Received: August 4, 2004.

Accepted: December 22, 2004.
}

DOI: 10.1097/01.GIM.0000159898.90221.D3 ria but warned that our inability to predict clinical status in full mutation female fetuses warranted further consideration. Finucan $\mathrm{e}^{11}$ argued that fragile $\mathrm{X}$ syndrome was particularly suited for population screening among unselected pregnant women, pointing out the diagnostic sensitivity of the DNAbased assay. Subsequent studies ${ }^{12-15}$ have demonstrated the efficacy of fragile X screening programs among women of reproductive age and concluded that carrier screening should be made more widely available to women in the general population. Most recently, widespread prenatal population-based screening has also been shown to be clinically desirable (identifying $98 \%$ of fragile $\mathrm{X}$-affected fetuses annually) and cost-effective. ${ }^{16}$

Genzyme Genetics and Yale University School of Medicine are both referral centers for women seeking prenatal genetic counseling services. Yale University began offering fragile X carrier screening to patients seeking prenatal genetic counseling in 1995. Genzyme Genetics initiated its fragile X carrier screening program in 2001. In this article, we will report on our centers' experience with 29,103 patients who were offered fragile $\mathrm{X}$ carrier screening as part of their genetic consultation. The purpose of this study was to (1) document the acceptance rate of fragile X carrier screening among a large population of prenatal patients seeking genetic counseling, (2) report on the carrier frequency among patients who accepted screening, and (3) present outcome data regarding prenatal testing for patients identified as carriers.

\section{METHODS}

During the calendar years of 2001 and 2002, a total of 29,103 preconceptional or pregnant women were offered fragile X carrier screening. Of these, 5,454 (19\%) were seen at the Yale University School of Medicine in Connecticut and 23,649 (81\%) were seen at select Genzyme Genetic sites throughout the United States. Fragile X carrier testing was offered on a 
strictly voluntary basis. Patients were referred for genetic counseling for a variety of reasons. Patients referred for or found to have a suspected or known family history of fragile $\mathrm{X}$ syndrome were excluded from the study.

All patients were given written information about fragile $\mathrm{X}$ syndrome before their genetic counseling appointment. Information included a brief description of fragile $\mathrm{X}$ syndrome, its inheritance, the reported carrier frequency among women in the general population, and the availability of carrier testing. During genetic counseling the genetic counselor reviewed the information sheet, answered any questions, and asked the patient if she was interested in fragile $\mathrm{X}$ carrier testing. If a patient responded "no," there was no further discussion of fragile $\mathrm{X}$ syndrome and the patient's decision regarding fragile $\mathrm{X}$ carrier testing was documented as a decline. If the patient responded "yes," the genetic counselor reviewed the natural history and genetics of fragile X syndrome, outlined the benefits and limitations of carrier and prenatal testing, and discussed the cost of fragile X DNA analysis. Beacuse fragile X carrier screening is not currently considered standard of care, patients were also informed that third party payers may not cover the cost of testing and, therefore, the patient was responsible for payment should she accept testing. Patients were asked if they wanted to have fragile X carrier testing. Responses were documented as accepted or declined.

Acceptance among women referred for genetic counseling was documented, and acceptance rates were compared among subsets of the study population. Women were divided into separate categories based on the primary referral indication. The referral groups (see Table 1) were as follows: (1) advanced maternal age ( $\geq 35$ y at delivery; $n=16,008)$, (2) positive multiple marker screening ( $n=6,738)$, (3) positive family history not suggestive of or consistent with a family history of fragile $\mathrm{X}$ syndrome (e.g., family history of birth defects, genetic disease, or mental retardation that does not follow a pattern of X linked inheritance; $n=4,401)$, (4) abnormal ultrasound $(n=1,102)$, (5) possible or known teratogenic exposure $(n=622)$, and (6) patient concern (women who were $<35 \mathrm{y}$ at delivery with no known significant history; $n=232$ ). Decisions about acceptance of an invasive procedure (CVS or amniocentesis) offered at the time of counseling because of an increased risk for chromosomal abnormalities was available for a subset $(15,691)$ of the women referred for advanced maternal age.

For patients who accepted fragile X carrier testing, blood samples were sent to Yale DNA Diagnostics Laboratory, Genzyme Genetics Molecular Diagnostic Laboratory or other laboratories as determined by a patient's insurance. Extracted DNA was tested by Southern blot and PCR analysis to determine FMR1 gene allele size(s) and methylation status. PCR analysis was performed using the method of Brown et al. ${ }^{17}$ Southern blot analysis was performed by the method of Rousseau et al. ${ }^{18}$

$F M R 1$ allele size was interpreted as either normal, intermediate, permutation, or full mutation using the same size definition categories recommended by the American College of Medical Genetics ${ }^{19}$ : normal $\leq 44$; intermediate 45 to 54 ; premutation 55 to 200; and full mutation $>200$ CGG repeats.

All premutation or intermediate allele carriers were referred for follow-up genetic counseling. Genetic counseling included a discussion of risks to the fetus and prenatal testing options. Patients were informed that no CGG repeat $<59$ had been found to expand to a full mutation in one generation in a large series of patients. ${ }^{20}$ For patients who accepted fragile X prenatal diagnosis, analysis of the FMR1 gene was accomplished by obtaining DNA from chorionic villi or cultured amniocytes. Methodology and CGG repeat category definitions were the same as that described for carrier testing.

Table 1

Fragile X carrier screening

\begin{tabular}{|c|c|c|c|}
\hline Referral indication & Accept & Decline & Total \\
\hline Advanced maternal age & $1574(9.8 \%)^{a}$ & 14434 & 16008 \\
\hline Positive multiple marker screening & $210(3.1 \%)^{b}$ & 6528 & 6738 \\
\hline Pos family history not suggestive of or consistent with FXS & $328(7.5 \%)$ & 4073 & 4401 \\
\hline Abnormal US & $64(5.8 \%)$ & 1038 & 1102 \\
\hline Possible or known teratogenic exposure & $21(3.4 \%)$ & 601 & 622 \\
\hline Patient concern ( $<35$ and no significant history) & $95(41 \%)^{c}$ & 137 & 232 \\
\hline Total & $2292(7.9 \%)$ & 26811 & 29103 \\
\hline \multicolumn{4}{|l|}{ Center } \\
\hline Yale & $394(7.2 \%)$ & 5060 & 5454 \\
\hline Genzyme & $1898(8.0 \%)$ & 21751 & 23649 \\
\hline Total & $2292(7.9 \%)$ & 26811 & 29103 \\
\hline
\end{tabular}

\footnotetext{
${ }^{a}$ Significantly different from the other 5 referral indication groups $(P<0.0001)$.

${ }^{b}$ Significantly lower than all other groups except teratogenic exposure group $(P<0.0001)$.

${ }^{c}$ Significantly higher than the other 5 referral indications combined $(P<0.0001)$.
} 


\section{RESULTS}

\section{Patient acceptance during counseling}

Overall 7.9\% of patients (2292) accepted fragile X carrier testing at the time of counseling. Logistic regression was used to compare acceptance rates in the different referral groups (Table 1). The acceptance rate was highest among the patient concern group (41\%) and was significantly higher than that observed among the other five referral indications combined $(P<0.0001)$. Conversely, the acceptance rate of the patients referred for positive multiple marker screening (3.1\%) was significantly lower than that of patients referred for advanced maternal age $(9.8 \%)$, positive family history of a disorder (excluding fragile $\mathrm{X}$ syndrome) (7.5\%), an abnormal ultrasound $(5.8 \%)$, or patient concern $(41 \%)(P<0.0001)$. The acceptance rate in the positive multiple marker screening group was not significantly different to that in the group referred for possible teratogenic exposure (3.4\%). Approximately, 10\% of the advanced maternal age patients accepted fragile $\mathrm{X}$ carrier screening.

Among the advanced maternal age group, we found that amniocentesis or CVS acceptance due to an increased risk for chromosomal abnormality was related to fragile $\mathrm{X}$ carrier testing acceptance. Women who accepted a procedure $(n=7906)$ were almost twice as likely to accept fragile $\mathrm{X}$ carrier testing than women who declined a procedure $(n=7785)(11.4 \%$ vs. $6.04 \% ; P<0.0001$ ) (see Table 2).

\section{Carrier testing and prenatal diagnosis results}

Among patients who elected fragile X carrier testing, DNA analysis detected 16 women or 1 in 143 with an intermediate allele (45-54 CGG repeats) and 6 women or 1 in 382 as having a premutation (55-200 CGG repeats). No full mutation was identified. The distribution of these alleles and primary reason for referral are shown in Tables 3 and 4.

Of the six women found to have a premutation, three elected to have fragile $\mathrm{X}$ prenatal diagnosis. Of the three who declined fragile X prenatal diagnosis, two had premutations in the 60 to 65 repeat range. Both of these patients had already been informed that they were carrying a cytogenetically abnormal fetus and elected to terminate their pregnancies based on these results alone. The third patient referred for advanced maternal age had a CGG repeat of 55. She declined fragile X prenatal diagnosis after genetic counseling based on the low risk of expansion to a full mutation and the female gender of the fetus. No further outcome information regarding this pregnancy is

Table 2

Comparison of fragile $\mathrm{X}$ carrier screening and prenatal testing among women with advanced maternal age

\begin{tabular}{lccc}
\hline & \multicolumn{3}{c}{ Fragile X carrier screening } \\
\cline { 2 - 4 } Prenatal procedure decision & Accepted & Declined & Total \\
\hline Accepted & $900(11.4 \%)$ & $7006(88.6 \%)$ & $7906(50.4 \%)$ \\
Declined & $497(0.4 \%)$ & $7288(93.6 \%)$ & $7785(49.6 \%)$ \\
\hline
\end{tabular}

Table 3

Prenatal testing among fragile $\mathrm{X}$ premutation carriers

\begin{tabular}{|c|c|c|c|c|}
\hline \multirow[b]{2}{*}{ Referral indication } & \multirow{2}{*}{$\begin{array}{c}\text { Maternal } \\
\text { CGG } \\
\text { No. }\end{array}$} & \multicolumn{3}{|c|}{ Prenatal fragile $\mathrm{X}$ testing } \\
\hline & & Acceptance & Sex & CGG No. \\
\hline AMA & 55 & $\mathrm{n}$ & N/A & \\
\hline AMA & 57 & $\mathrm{y}$ & Male & 30 \\
\hline $\begin{array}{l}\mathrm{FOP}^{a} \text { Family } \\
\text { history }\end{array}$ & 60 & $y$ & Male & 20 \\
\hline Positive $\mathrm{MMS}^{b}$ & 65 & $\mathrm{n}$ & N/A & \\
\hline AMA & 74 & $\mathrm{y}$ & Female & $29 ; 74$ \\
\hline AMA & $60-65$ & $\mathrm{n}$ & N/A & \\
\hline
\end{tabular}

${ }^{a}$ Father of pregnancy.

${ }^{b}$ Multiple marker screening.

Table 4

Prenatal testing among fragile $\mathrm{X}$ intermediate allele carriers

\begin{tabular}{|c|c|c|c|c|}
\hline \multirow[b]{2}{*}{ Referral indication } & \multirow{2}{*}{$\begin{array}{c}\text { Maternal } \\
\text { CGG } \\
\text { No. }\end{array}$} & \multicolumn{3}{|c|}{ Prenatal fragile $\mathrm{X}$ testing } \\
\hline & & Acceptance & Sex & CGG No. \\
\hline AMA & 45 & $\mathrm{y}$ & Male & 45 \\
\hline AMA & 45 & $\mathrm{y}$ & Male & 45 \\
\hline History MPS III ${ }^{a}$ & 45 & $\mathrm{y}$ & Female & $24 ; 45$ \\
\hline Ethnicity & 45 & $\mathrm{n}$ & N/A & \\
\hline History diabetes; ethnicity & 45 & Not indicated & N/A & \\
\hline Patient concern & 46 & $\mathrm{n}$ & N/A & \\
\hline AMA & 46 & $\mathrm{y}$ & Male & 50 \\
\hline Multiple gestation & 46 & $\mathrm{n}$ & N/A & \\
\hline AMA & 47 & $\mathrm{y}$ & Male & 48 \\
\hline AMA & 47 & $\mathrm{n}$ & N/A & \\
\hline AMA & 49 & $\mathrm{y}$ & Male & 54 \\
\hline Known $\mathrm{CF}^{b}$ carriers & $45-50$ & $\mathrm{n}$ & N/A & \\
\hline Ethnicity & 50 & Not indicated & N/A & \\
\hline AMA & 52 & $\mathrm{y}$ & Male & 52 \\
\hline AMA & $45-55$ & $\mathrm{n}$ & N/A & \\
\hline AMA & $50-55$ & $\mathrm{n}$ & N/A & \\
\hline
\end{tabular}

${ }^{a}$ Mucopolysaccharidosis type III or Sanfilippo syndrome.

${ }^{b}$ Cystic fibrosis.

available. Of the three women who accepted fragile $\mathrm{X}$ prenatal diagnosis, two (with 57 and 60 CGG repeats, respectively) were found to be carrying normal male fetuses (they transmitted their normal allele), whereas one woman (with 74 CGG repeats) had a female fetus shown to be a premutation carrier. The mother's CGG repeat was transmitted intact, without expansion, in this instance (see Table 3).

Among the 16 women found to have an intermediate-sized allele, all were counseled that no CGG repeat less than 59 had been observed to expand to a full mutation in one generation. Fourteen of these women were offered prenatal diagnosis for a 
reason unrelated to fragile X syndrome. In those 14 women, two declined prenatal diagnosis (no fetal sampling was performed for any reason) and 12 accepted prenatal diagnosis. Among the 12 undergoing fetal sampling, seven requested prenatal fragile $\mathrm{X}$ analysis. The seven maternal-fetal pairs demonstrated the following transmissions of the intermediate allele: four without change (45, 45, 45, 52 CGG repeats, respectively) and three with expansion of the allele ( 46 to 50,47 to 48 , and 49 to 54 CGG repeats) (see Table 4).

\section{DISCUSSION}

The American College of Medical Genetics Policy Statement on fragile X syndrome diagnostic and carrier testing ${ }^{9}$ recommends population carrier screening only as part of a well-defined clinical research protocol. Since publication of the Policy Statement, only one study has provided data on patient acceptance of fragile X carrier screening among women of reproductive age. This study was conducted in Finland by Ryynanen et al. ${ }^{12}$ on women seeking prenatal care who did not have a family history of fragile X syndrome. During the initial visit, women were given a brochure about fragile $\mathrm{X}$ syndrome and fragile $\mathrm{X}$ DNA analysis was offered free of charge. Among the 1738 women who participated in the study, $85 \%$ (1477) elected to have fragile X carrier testing. This differs significantly from our overall acceptance rate of $7.8 \%$. In comparing the two studies, several factors appear to be influencing patient decision-making. One is the cost of carrier testing. It is likely that a higher percentage of women will accept fragile $\mathrm{X}$ carrier testing if they are not responsible for this expense. Patients in our study were informed that the cost of testing could be as high as $\$ 350$ and that third party payers may not cover the cost of fragile X DNA analysis. In addition, whether fragile $\mathrm{X}$ syndrome carrier testing was offered in isolation or as part of a panel of optional carrier screening tests, may also account for differences in acceptance rates. Race, cultural factors, religion, parental age, number of previous children, and socioeconomic status may have also influenced women's decisions regarding testing but this data were not available for analysis.

As our study has also shown, referral indication and uptake of an invasive prenatal diagnostic test are significant influencing factors. Women referred because of patient concern and women referred for advanced maternal age, especially those who accepted an amniocentesis or CVS, demonstrated the highest acceptance. Conversely, positive multiple marker screening was associated with the lowest acceptance, followed by women referred because of a possible teratogenic exposure. Perhaps these women are more preoccupied with their referral indication at the time of counseling and additional information about genetic risks unrelated to their primary concern is weighed differently or is more overwhelming than for other groups. Further study is necessary to investigate this issue and evaluate other, more effective ways to make fragile $\mathrm{X}$ carrier testing information available to this subset of women.

An important measure of the effectiveness of a carrier screening program is the frequency and effectiveness of carrier detection. Rousseau et al. ${ }^{7}$ were the first to perform a largescale retrospective study on the frequency of premutation alleles. They found that the carrier frequency among women in the general population was 1 in 259. This study included 10,624 unselected women in whom 41 women with a CGG repeat $>55$ were identified. These blood samples were obtained anonymously through a hematology laboratory in Quebec and included women with a family history of mental retardation. A subsequent Finnish study of women seeking prenatal care $^{12}$ excluded patients with a known family history of fragile $\mathrm{X}$ syndrome $(n=1,477)$. In this study, six women ( 1 in 246$)$ were found to have a CGG repeat $>60$. A later study by Pesso et al. ${ }^{13}$ included 9,459 women of reproductive age who were self referred or referred by their gynecologist for fragile X DNA analysis. Of these, 1,033 women reported a family history of mental retardation or developmental problems and were separated from those considered at low risk. Among the low risk group $(n=8,426), 123$ women were found to have a CGG repeat $\geq 52$. Of these, 59 ( 1 in 143) were identified with CGG repeats of $\geq 55$. This included one woman with a full mutation. In 2001, Toldedano-Alhadef et al. ${ }^{14}$ performed fragile X DNA analysis on 14,334 Israeli women of reproductive age. Their study included preconceptional and pregnant women and excluded those with a family history of mental retardation. One hundred and twenty seven women with $\geq 55$ CGG repeats were identified ( 1 in 113), three of which were found to have the full mutation. A second screening study conducted in Israel of 34,014 women with no family history of mental retardation or learning disabilities, ${ }^{15}$ identified 221 women with CGG repeats $>55$ (including one full mutation) for an overall carrier frequency of 1 in 154 . The premutation carrier frequency in our study, 1 in 380, excludes women with any family history suspicious of fragile X syndrome (mental retardation, developmental delay, and autism). There are several explanations why the current study most likely identified a lower carrier frequency. These include founder effects that have been described in the Finnish and Israeli populations ${ }^{21,22}$ and differences in exclusion criteria. It may also be possible that premutation and full mutation women, who present with subtle emotional or cognitive involvement, ${ }^{23}$ might be overwhelmed by the amount of information and options presented during a genetic counseling session and decide not to participate.

One potential problem associated with carrier screening is detection of women with intermediate alleles. In our study, the intermediate allele frequency was 1 in 143 . This compares to a previous study that suggested the intermediate allele frequency may be as high as 1 in 52.24 Despite advances in our understanding of CGG repeat instability, management of women with intermediate alleles remains challenging. Current opinion is to perform family studies, when possible, to determine allele instability within a given family. Women should also be counseled that there have been no reports of a CGG repeat $<59$ expanding to a full mutation when passed from mother to offspring. ${ }^{20}$ Although we followed these guidelines when counseling the intermediate allele carriers in our study, we found patients still felt unsettled by their carrier testing results. As 
noted in our study, $70 \%$ of women with an intermediate allele who were having amniocentesis for another reason, requested fragile X prenatal diagnosis for reassurance. As expected, no CGG repeat in the intermediate allele range expanded to a full mutation when passed from mother to offspring.

Patients seeking prenatal genetic counseling are often referred because of an increased risk for mental retardation. Many patients are concerned about their risk for having a child with Down syndrome, the most well-known cause of mental retardation. These same women, however, are unaware of the risk for fragile $\mathrm{X}$ syndrome. Today, it is standard of care to offer routine screening for other debilitating or devastating genetic conditions that have a similar frequency to fragile $\mathrm{X}$ syndrome (e.g., cystic fibrosis, Tay-Sachs and Canavan disease among the Ashkenazi Jewish population). This provides further rationale for offering fragile $\mathrm{X}$ carrier screening given the comparable frequency and burden of the disorder.

The cost of fragile $\mathrm{X}$ testing is not high in the context of the overall cost of prenatal diagnosis and the benefits to individual families can be enormous. One model, designed to evaluate the cost effectiveness of widespread fragile X screening compared the outcomes of screening versus not screening for the fragile $\mathrm{X}$ FMR1 premutation. ${ }^{16}$ Outcome measures included societal costs of the screening strategy, the number of procedure-related losses, the number of fragile $\mathrm{X}$ fetuses identified, and a cost per quality adjusted life-year (QALY) ratio. The authors concluded that screening would lead to the identification of $98 \%$ of fragile X-affected fetuses annually and may be costeffective depending on the cost of screening and the number of offspring. A separate study examined the attitudes and perspectives of fragile $\mathrm{X}$ families regarding screening. ${ }^{25}$ Parents were generally supportive and saw benefits in making voluntary carrier screening for fragile $\mathrm{X}$ syndrome available more broadly.

Our study suggests that fragile $\mathrm{X}$ carrier screening is an acceptable option for some women seeking prenatal genetic counseling. As with other conditions, we have found that information necessary for informed decision-making regarding fragile X carrier screening can be presented effectively and efficiently. Based on our experience, the reported carrier frequency among women of reproductive age, the potential cost effectiveness of screening, and the ability to accurately identify this disorder, it seems good medical practice to make information regarding the most common inherited cause of mental retardation available to patients seeking reproductive genetic counseling. Patients who are found to be carriers should be referred for genetic counseling and be given the option of fragile $\mathrm{X}$ prenatal diagnosis.

\section{ACKNOWLEDGMENTS}

The authors acknowledge Shirley Lin and Denise Ramsey for their indispensable assistance with data collection.

\section{References}

1. Lubs HA. A marker X chromosome. Am J Hum Genet 1969;21:231-244.

2. Fu YH, Kuhl DPA, Pizzuti A, Pieretti M, Sutcliff JS, Richard S et al. Variation of the CGG repeat at the fragile $\mathrm{X}$ site results in genetic instability: Resolution of the Sherman paradox. Cell 1991;67:1047-1058.

3. Kremer EJ, Pritchard M, Lynch M, Yu S, Holman K, Baker E et al. Mapping of DNA instability at the fragile X to a trinucleotide repeat sequence $\mathrm{p}(\mathrm{CCG}) \mathrm{n}$. Science 1991; 252:1711-1714.

4. Oberle I, Rousseau F, Heitz D, Kretz D, Devys D, Honauer A et al. Instability of a 550-base pair DNA segment and abnormal methylation in fragile X syndrome. Science 1991;252:1097-1102.

5. Verkerk AJ, Pleretti M, Sutcliff JS, Fu YH, Kuhl DPA, Pizutti A et al. Identification of a gene (FMR1) containing a CGG repeat coincident with a breakpoint cluster region exhibiting length variation in fragile X syndrome. Cell 1991;65:905-914.

6. Turner G, Webb T, Wake S, Robinson H. Prevalence of fragile X syndrome. Am J Med Genet 1996;64:196-197.

7. Rousseau F, Rouillard P, Morel ML, Khandjian EW, Morgan K. Prevalence of carriers of permutation-sized alleles of the FMR1 gene- and implications for the population genetics of fragile X syndrome. Am J Hum Genet 1995;57:1006-1018.

8. Rousseau F, Morel ML, Rouillard P, Khandjian EW, Morgan K. Surprisingly low prevalence of FMR1 premutations among males from the general population ( $\mathrm{ab}$ stract) Am J Hum Genet 1996;59(suppl):A188:1069.

9. American College of Medical Genetics. Policy Statement: Fragile X syndrome: Diagnostic and carrier testing. Am J Med Genet 1994;53:380-381.

10. Palomaki GE. Population based prenatal screening for the fragile X syndrome. J Med Screen 1994;1:65-72.

11. Finucane B. Should all pregnant women be offered carrier testing for fragile $\mathrm{X}$ syndrome? Clin Obstet Gynecol 1996;39:772-781.

12. Ryynanen M, Heinonen S, Makkonen M, Kajanoja, Mannermaa A, Pertti K. Feasibility and acceptance of screening for fragile $\mathrm{X}$ mutations in low-risk pregnancies. Eur J Hum Genet 1999;7:212-216.

13. Pesso R, Berkenstadt M, Cuckle H, Gak E, Peleg L, Frydman M et al. Screening for fragile X syndrome in women of reproductive age. Prenat Diagn 2000;20:611-614.

14. Toledano-Alhadef H, Basel-Vanagaite L, Magal N, Davidov B, Ehrlich S, Drasinover $\mathrm{V}$ et al. Fragile-X carrier screening and the prevalence of premutation and fullmutation carriers in Israel. Am J Hum Genet 2001;69:351-360.

15. Berkenstadt M, Ries-Levavi L, Goldman B, Spiegel M, Gerard L, Cuckle H et al Prenatal and preconceptional screening for fragile $\mathrm{X}$ syndrome: experience with 37,000 tests. Paper presented at American Society of Human Genetics Annual Meeting. Toronto, October 26-30, 2004.

16. Musci TJ, Caughey AB. Cost-effectiveness analysis of prenatal population-based fragile X carrier screening. Am J Obstet Gynecol 2003;189:A197:S117.

17. Brown WT, Houck GE Jr, Jeziorowska A, Levinson FN, Ding X, Dobkin C et al. Rapid fragile $\mathrm{X}$ carrier screening and prenatal diagnosis using a nonradioactive PCR test. JAMA 1993;270:1569-1575.

18. Rousseau R, Heitz D, Biancalana V, Blumenfeld S, Kretz C, Boue J et al. Direct diagnosis by DNA analysis of the fragile $\mathrm{X}$ syndrome of mental retardation. $\mathrm{N}$ Engl J Med 1991;325:1673-1681.

19. Maddalena A, Richards CS, McGinniss MJ, Brothman A, Desnick RJ, Grier RE et al. Technical standards and guidelines for fragile X: The first of a series of diseasespecific supplements to the standards and guidelines for clinical genetics laboratories of the American College of Medical Genetics. Quality Assurance Subcommittee of the Laboratory Practice Committee. Genet Med 2001;3:200-205.

20. Nolin SL, Brown WT, Glicksman A, Houck GE Jr, Gargano AD, Sullivan A et al. Expansion of the fragile X CGG repeat in females with premutation or intermediate alleles. Am J Hum Genet 2003;72:454-464.

21. Zhong N, Kajanoja E, Smits B, Pertrofesa D, Curley D, Wang D et al. Fragile X founder effects and new mutations in Finland. Am J Med Genet 1996;64:226-233.

22. Song FJ, Barton P, Sleightholme V, Yao GL, Fry-Smith A. Screening for fragile X syndrome: a literature review and modeling study. Health Technol Assess 2003;7:1106.

23. Johnston C, Eliez S, Dyer-Friedman J, Hessl D, Glaser B, Balsey C et al. Neurobehavioral phenotype in carriers of the fragile X premutation. Am J Med Genet 2001; 103:314-319.

24. Murray A, Youings S, Dennis N, Latsky L, Linehan P, McKechnie N et al. Population screening at the FRAXA and FRAXE loci: molecular analyses of boys with learning difficulties and their mothers. Hum Mol Genet 1996;5:727-735.

25. Skinner D, Sparkman KL, Bailey DB. Screening for fragile X syndrome: Parent attitudes and perspectives. Genet Med 2003;5:378-384. 